Dian Utami Mas Bakar: Pengujian Konstitusional

\title{
PENGUJIAN KONSTITUSIONAL UNDANG-UNDANG PENGESAHAN PERJANJIAN INTERNASIONAL
}

\author{
Dian Utami Mas Bakar \\ dianutamimasbakar91@yahoo.com \\ Fakultas Hukum Universitas Hasanuddin
}

\begin{abstract}
This research aims to analyze normatively about the nature of the act of the ratification of international treaties and outlines the act of constitutional review to the ratification of international treaties. The results of research shows: 1) the standing of international treaties is dependent on the scores of international law who espoused a country. Ratification of a treaty embodied through the two phases namely: the phases of the national law and of international law; 2) the meaning of "DPR approval" must be viewed in the context of internal procedures meanwhile ratification must be vied of external procedure. 3) Constitutional review may results in wide and problematic decision. If it is declared void then execution of the decision will face obstacles. If there is a denunciation, Government is in the difficult position and even can trigger dispute to the international Court of Justice.
\end{abstract}

Keywords: ratification, international agreement, legislation

\begin{abstract}
Abstrak
Penelitian ini bertujuan untuk menganalisis secara normatif hakikat undang-undang pengesahan perjanjian internasional dan akibat hukum pengujian konstitusional undang-undang pengesahan perjanjian internasional. Hasil penelitian menunjukkan: 1) Kedudukan perjanjian internasional bergantung pada kedudukan hukum internasional yang dianut suatu negara. Ratifikasi perjanjian internasional diwujudkan melalui dua tahapan, yaitu tahapan hukum nasional dan tahapan hukum internasional; 2) Makna "persetujuan DPR" yang melakukan pengesahan perjanjian internasional harus dipandang dalam konteks prosedur internal sementara ratifikasi sebagai prosedur eksternal; 3) Pengujian konstitusional dapat menimbulkan akibat hukum yang cukup luas dan problematik. Jika dinyatakan batal maka pelaksanaan putusan tersebut menghadapi kendala, karena belum ada mekanisme yang disuguhkan tentang bagaimana tata cara pelaksanaan putusannya. Meskipun misalnya melalui penarikan diri, posisi Pemerintah akan mengalami kesulitan. Dampak politik juga akan muncul jika penrikan diri Pemerintah dipersengketakan ke Mahkamah Internasional oleh negara peserta perjanjian yang lain.
\end{abstract}

Kata Kunci: ratifikasi, perjanjian internasional, undang-undang 


\section{Pendahuluan}

Konsep Negara Hukum yang tertuang dalam Pasal 1 ayat (3)Undang-Undang Dasar Negara Republik Indonesia Tahun 1945 (selanjutnya disebut UUDNRI 1945) dipahami sebagai jaminan formal bahwa Indonesia adalah negara yang berdasarkan hukum.Dalam suatu negara hukum,selain mengharuskan adanya pengakuan secara empiris yang terwujud dalam perilaku pemerintahan dan masyarakat yang mendasarkan diri pada aturan hukum, jugamengharuskan adanya pengakuan normatif terhadap prinsip supremasi hukum, yaitu bahwa semua masalah diselesaikan dengan hukum sebagai pedoman tertinggi.Pengakuan normatif mengenai supremasi hukum terwujud dalam pembentukan norma hukum secara hirarkis yang berpuncak pada supremasi konstitusi. ${ }^{1}$

Prinsip supremasi konstitusi ini memandang konstitusi sebagai hukum yang paling tinggi serta paling fundamental sifatnya, karena konstitusi merupakan sumber legitimasi atau landasan otorisasi bentuk-bentuk hukum atau peraturan perundang-undangan lainnya. Sesuai dengan prinsip hukum yang berlaku universal, agar peraturan perundang-undangan yang tingkatannya berada di bawah Undang-Undang Dasar (UUD) dapat berlaku dan diberlakukan, peraturan-peraturan itu tidak boleh bertentangan dengan hukum yang lebih tinggi. ${ }^{2}$ Hal ini juga dipertegas dalam undang-undang (selanjutnya disingkat UU 12/2011) yaitu pada Pasal 7 Ayat (2) UU Nomor 12 Tahun 2011 tentang Pembentukan Peraturan Perundang-Undangan ${ }^{3}$ (selanjutnya disebut UU Pembentukan Peraturan Perundang-undangan) bahwa kekuatan hukum atas peraturan perundang-undangan harus berdasarkan hierarki. Terdapat tiga ciri utama yang menandai prinsip supremasi konstitusi, yaitu: 1) Pembedaan antara norma hukum konstitusi dan norma hukum lainnya; 2) Keterikatan penguasa terhadap Undang-Undang Dasar; 3) Terdapat satu lembaga yang memiliki kewenangan untuk menguji konstitusionalitas undang-undang dan tindakan hukum Pemerintahan. ${ }^{4}$

Atas dasar itu maka melahirkan konsekuensi logis adanya instrumen untuk menafsirkan dan menguji (apakah bertentangan atau tidak) materi peraturan perundang-undangan yang disebut dengan pengujian konstitusional atau constitutional review ${ }^{5}$ yang dilakukan oleh

\footnotetext{
1 Jimly Asshiddiqie, Gagasan Dasar tentang Konstitusi dan Mahkamah Konstitusi, Artikel Ketua Mahkamah Konstitusi, h. 18.

2 Jimly Asshiddiqie, Konstitusi \& Konstitusionalisme Indonesia, Sinar Grafika, Jakarta Timur, 2010, h. 19.

3 Lembaran Negara Republik Indonesia Tahun 2011 Nomor 82.

4 Maruarar Siahaan, "Checks and Balances dan Judicial Review dalam Legislasi di Indonesia", www. jimlyschool.com/read/analisis/333/checks-and-ba;lances-dan-judicial-review-dalam-legislasi-di-indonesia,3 Juli 2012, dikunjungi pada tanggal 9 Juni 2013, dikutip dari Jutta Limbach, The Concept of The Supremacy of the Constitution dalam “The Modern Law Review”, Vol. 64, No. 1, Januari, 2001, h. 3.

5 Istilah Constitutional review, bukan Judicial review. Hakekatnya, terdapat perbedaan istilah Judicial review (pengujian legalitas) dan Constitutional review (pengujian konstitusional). Perbedaan pertama, constitutional review selain dilakukan oleh hakin dapat pula dilakukan oleh lembaga selain hakim atau pengadilan, tergantung kepada lembaga mana konstitusi memberikan kewenangan untuk melakukannya. Kedua, dalam konsep judicial review terkait pula pengertian yang lebih luas objeknya, misalnya mencakup soal legalitas perauran di bawah UU terhadap UU, sedangkan constitutional review hanya menyangkut pengujian konstitusionalnya, yaitu terhadap UUD/Konstitusi. Lihat Jimly Asshiddiqie, Model-Model Pengujian Konstitusional di Berbagai Negara, Konstitusi Press, Jakarta, 2005, h. 3.
} 
Mahkamah Konstitusi berdasarkan Pasal 24C Ayat (1) UUDNRI 1945 yang mengatur bahwa Kewenangan menguji yang ada pada Mahkamah Konstitusi dapat dilakukan dalam bentuk pengujian formal dan pengujian materil. ${ }^{6}$ Objek pengujiannya adalah undang-undang terhadap UUD. Namun, bentuk UU dalam sistem hukum nasional Indonesia tidak semuanya seragam dan lazim sesuai dengan ketentuan pembentukan peraturan perundang-undangan. Terdapat bentuk UU yang memiliki karakter khusus atau perbedaan mendasar baik terkait pembentukan formal $^{7}$ maupun materilnya. Hal ini dapat dilihat sebagaimana eksistensi Undang-Undang Pengesahan Perjanjian Internasional yang merupakan bentuk UU dimana materi normatifnya adalah perjanjian internasional (sebagai lampiran dari UU tersebut) yang pada dasarnya tunduk pada hukum internasional.

Kehadiran bentuk Undang-Undang Pengesahan Perjanjian Internasional ini lahir sebagai “persetujuan DPR" sesuai amanah konstitusi Pasal 11 UUD NRI 1945 ayat (2) mengatur bahwa Presiden dalam membuat perjanjian internasional lainnya yang menimbulkan akibat yang luas dan mendasar bagi kehidupan rakyat yang terkait dengan beban keuangan negara, dan/ atau mengharuskan perubahan atau pembentukan undang-undang harus dengan persetujuan Dewan Perwakilan Rakyat. Sebagai perundang-undangan lebih lanjut, maka dibentuk UU Nomor 24 Tahun 2000 tentang Perjanjian Internasional ${ }^{8}$ (selanjutnya disingkat UU Perjanjian Internasional), dimana Pasal 9 mengatur bahwa pengesahan perjanjian internasional dilakukan sepanjang dipersyaratkan dan dituangkan dalam bentuk Undang-Undang atau Keputusan Presiden. Selanjutnya, Pasal 10 UU Perjanjian Internasional mengatur bahwa pengesahan perjanjian internasional dilakukan dengan undang-undang apabila berkenaan dengan: a) Masalah politik, perdamaian, pertahanan, dan keamanan negara; b) Perubahan wilayah atau penetapan batas wilayah negara Republik Indonesia; c) Kedaulatan atau hak berdaulat negara; d) Hak asasi manusia dan lingkungan hidup; d) Pembentukan kaidah hukum baru; e) Pinjaman dan/atau hibah luar negeri.

Uraian pasal tersebut menunjukkan bahwa pembentukan perjanjian internasional atau ratifikasi oleh pemerintah harus mendapat persetujuan dari DPR sepanjang ratifikasi dipersyaratkan oleh perjanjian internasional tersebut. Kemudian dipertegas dalam Pasal 10 UU Perjanjian Internasional bahwa dalam hal tertentu persetujuan DPR tersebut dibuat dalam bentuk UU pengesahan. Secara teoritis, jika perjanjian internasional tersebut harus disahkan melalui bentuk UU, maka perlu diketahui kedudukan dan hakikatUndang-Undang Pengesahan

\footnotetext{
$6 \quad$ Lihat Pasal 51, Pasal 51A UU Nomor 24 Tahun 2003 Tentang Mahkamah Konstitusi Sebagaimana telah diubah dengan UU Nomor 8 Tahun 2011 Tentang Perubahan Atas Undang-Undang Nomor 24 Tahun 2003 Tentang Mahkamah Konstitusi.

7 Misalnya Peraturan Pemerintah sebagai Pengganti Undang-Undang/Perpu. Materi muatannya adalah materi muatan UU tetapi situasi yang dihadapi dalam kegentingan yang memaksa atau keadaan darurat sehingga materi norma yang perlu diatur itu tidak mungkin dituangkan dalam bentuk UU, maka diberlakukan sementara waktu meski sebelum ada persetujuan DPR, sehingga dengan demikian dapat dilihat bahwa bentuk Perpu yang disetarakan dengan UU ini memiliki prosedur/formil yang berbeda. Lihat Jimly Asshiddiqie, Hukum Acara Pengujian Undang-Undang, Yarsif Watampone, Jakarta, 2005, h. 43-44.

8 Lembaran Negara Republik Indonesia Tahun 2000 Nomor 185
} 
Perjanjian Internasional itu sendiri dalam sistem Peraturan Perundang-undangan Nasional karena khusus dalam Undang-Undang Pengesahan Perjanjian Internasional terdapat ranah hukum internasional yang saling berhadapan dengan hukum nasional. Oleh karena itu, apa “original intent" penuangan 'persetujuan DPR' (berdasar Pasal 11 UUDNRI 1945) terhadap perjanjian internasional dalam bentuk undang-undang. Apakah pemberian persetujuan itu dapat dilihat sebagai bentuk urusan administrasi/perwujudan formal untuk memenuhi amanah konstitusi (sehingga sebagai UU formal saja) ataukah bentuk persetujuan itu menimbulkan Undang-Undang Pengesahan Perjanjian Internasional memiliki kedudukan yang sama dengan undang-undang pada umumnya, yang materi normatifnya serta merta berlaku dalam negara Indonesia dan dapat dilakukan pengujian, meskipun disadari bahwa perjanjian internasional adalah tunduk pada hukum internasional dan terikat dengan negara-negara lain.

Pada dasarnya, dilihat dari bentuknya, maka Undang-Undang Pengesahan Perjanjian Internasional memiliki ciri tersendiri dimana dapat dikatakan tidak memenuhi sebagai wet in materiele zijn karena materi normatif dalam UU ini adalah Perjanjian Internasional yang dilakukan oleh negara/pihak-pihak dengan melalui proses pembuatan perjanjian internasional di bawah sistem hukum internasional. Perjanjian internasional sebagai materi normatifnya menjadi bagian lampiran dalam UU Pengesahan tersebut, dan bukan isi pasal/batang tubuh ${ }^{9}$ dari UU tersebut.

Meskipun demikian, keberadaan undang-undangnya tidak mungkin dipisahkan dari naskah perjanjian internasional yang disahkan. Karena itu, jika undang-undangnya diuji, maka dengan sendirinya materi perjanjian internasional yang menjadi lampiran undang-undang itu dapat saja dipersoalkan oleh pemohon, sebagaimana telah diatur dalam Penjelasan dalam Lampiran II huruf F UU Pembentukan Peraturan Perundang-undangan bahwa dalam hal peraturan perundang-undangan memerlukan lampiran, hal tersebut dinyatakan dalam batang tubuh bahwa lampiran dimaksud bagian yang tidak terpisahkan dari peraturan perundangundangan.

Perkara riil yang mengajukan permohonan pengujian materil terhadap UndangUndang Pengesahan Perjanjian Internasional kepada Mahkamah Konstitusi telah ada berdasarkan Putusan Nomor: 33/PUU-IX/2011. Pada amar putusannya, Mahakamah Konstitusi berkesimpulan bahwa Mahkamah berwenang untuk mengadili permohonan a quo, meskipun dua Hakim memiliki dissenting opinion. Namun, kewenangan Mahkamah Konstitusi dalam pengujian ini menurut penulis masih perlu dikaji lagi.

Di satu sisi, lampiran undang-undang adalah bagian yang tidak terpisahkan dari undang-undang itu sendiri. ${ }^{10}$ Dengan demikian secara praktis dapat dikatakan bahwa pengujian

9 Undang-Undang Pengesahan Perjanjian Internasional hanya memuat 2 pasal, yaitu pasal 1 memuat pengesahan perjanjian internasional dengan memuat pernyataan melampirkan salinan naskah asli dan terjemahannya dalam Bahasa Indonesia dan pasal 2 memuat ketentuan mengenai saat mulai berlaku. Sedangkan naskah perjanjian internasional sebagai materi normatifnya diuraikan dalam lampiran UU tersebut. Lihat Lampiran II BAB II HalHal Khusus UU Nomor 12 Tahun 2011 tentang Pembentukan Peraturan Perundang-undangan.

10 Lihat UU Nomor 12 Tahun 2011 tentang Pembentukan Peraturan Perundang-Undangan. 
undang-undang terhadap UUD dapat dilakukan untuk menilai konstitusionalitasnya. Namun jika dilakukan pengujian materil (yaitu perjanjian internasional), perjanjian internasional yang otentik merupakan produk yang tunduk pada hukum internasional ${ }^{11}$ yang oleh Indonesia tidak mungkin ditolak sebagian dan diterima sebagian lainnya setelah dilakukan prosedur ratifikasi oleh Indonesia. ${ }^{12}$ Oleh karena itu dapat dilihat terjadinya konflik norma atau pertentangan antara hukum internasional dan hukum nasional dalam kaitan terhadap pengujian Undang-Undang Pengesahan Perjanjian Internasional ini. Selain itu, pembatalan materi normatif dalam perjanjian internasional juga harus memerhatikan ketundukan Indonesia dalam hukuminternasional yaitu berdasar Konvensi Wina Tahun 1969 tentang Hukum Perjanjian Internasional. Pada Pasal 27 mengatur bahwa: A party may not invoke the provisions of its internal law as justification for its failure to perform a treaty. This rule is without prejudice to article $46 .{ }^{13}$

Berdasarkan hal tersebut maka hukum internasional tidak memperkenankan penggunaan alasan hukum nasional untuk tidak melaksanakan kewajiban dalam suatu perjanjian internasional yang telah diratifikasinya. Oleh karena itu, jika praktek pengujian ini dilakukan maka perlu mengkaji juga mengenai akibat hukum pembatalan perjanjian internasional secara sepihak ini. Dimana terhadap perjanjian internasional yang telah disahkanbisa saja menimbulkan hak dan kewajiban antara negara yang saling mengikatkan diri dalam sebuah perjanjian internasional. Jika hak-hak yang telah ditimbulkan oleh sebuah perjanjian internasional dihapuskan secara sepihak saja, maka pihak (negara) yang dirugikan dapat mempertahankan haknya di depan Mahkamah Internasional atau dengan cara sebagaimana yang ditentukan dalam perjanjian internasional yang bersangkutan. ${ }^{14}$

Berdasarkan seluruh uraian di atas, maka fokus pembahasan tulisan ini mengarah pada hakikat Undang-Undang Pengesahan Perjanjian Internasional kemudian menghubungkannya dengan akibat hukum pengujian konstitusional Undang-Undang Pengesahan Perjanjian Internasional oleh Mahkamah Konstitusi.

\section{Kedudukan Perjanjian Internasional dalam Sistem Hukum Indonesia}

Pada negara-negara hukum modern, pengembangan doktrin tentang hubungan hukum internasional dan nasional telah bergulir sejak awal abad ke-20 melalui proses wacana publik yang cukup panjang termasuk pada proses legislasi maupun yurisprudensi yang akhirnya terkristalisasi dalam suatu pilihan politih hukum baik monoisme, dualisme maupun kombinasi keduanya. Pada negara-negara tersebut, persoalan status hukum internasional, baik hukum nasional mereka telah tuntas. ${ }^{15}$ Namun, bagi Indonesia kedudukan perjanjian internasional dalam hukum nasional masih belum jelas. Hukum, doktrin dan praktik Indonesia tentang status

11 Bahwa suatu perjanjian internasional harus dimaksudkan governed by international law berdasarkan defenisi perjanjian internasional menurut Konvensi Wina.

12 Jimly Asshiddiqie, Hukum Acara Pengujian Undang-Undang, Op.Cit., h. 49.

13 Terjemahan bebas.

14 Harjono, Op.Cit., h. 135-136.

15 Damos Dumoli Agusman, Op.Cit., h. 98. 
perjanjian internasional dalam hukum nasional Indonesia belum berkembang dan acapkali menimbulkan persoalan praktis dalam tataran implementasi perjanjian internasional di dalam kerangka sistem hukum nasional. Ketidakjelasan ini merupakan bagian dari ketiadaan hukum maupun doktrin pada sistem hukum Indonesia tentang hubungan hukum internasional dan hukum nasional. Sehingga terjadi kebingungan dalam dunia praktisi dalam menjawab status perjanjian internasional dalam hukum nasional. ${ }^{16}$

Ketentuan mengenai Perjanjian Internasional dalam sistem hukum Indonesia diatur dalam konstitusi Indonesia, berdasarkan Pasal 11 UUDNRI Tahun 1945 bahwa Presiden dengan persetujuan DPR menyatakan perang, membuat perdamaian dan perjanjian dengan negara lain. Berdasarkan ketentuan tersebut maka dapat dijelaskan bahwa tentang mengadakan perjanjian dengan negara lain, negara-negara antara lain mengadakan perjanjian internasional antar sesama negara maupun dengan lembaga-lembaga internasional, baik yang bersifat bilateral maupun multilateral. Semuanya itu tunduk pada prinsip-prinsip dan kaedah-kaedah hukum perjan jian internasional baik yang masih berbentuk hukum kebiasaan internasional maupun yang sudah dituangkan dalam bentuk konvensi internasional seperti misalnya Konvensi Wina 1986 tentang Hukum Perjanjian Internasional antara Negara dengan Organisai Internasional. ${ }^{17}$

Tampaknya yang dimaksudkan dengan perkataan "membuat perjanjian dengan negara lain" tersebut adalah dalam arti luas yakni perjanjian bilateral maupun mulilateral. Sudah tentu pula termasuk mengikatkan diri atau menjadi peserta dalam suatu perjanjian internasional yang sudah ada dan berlaku sebagai hukum internasional positif. Persoalan mengenai persetujuan DPR, sangat erat kaitannya dengan kedudukan dan fungsi DPR sebagai lembaga perwakilan yang mewakili dan menyuarakan kepentingan rakyat. Persetujuan itu dimintakan terhadap hasil kesepakatan antara pemerintah dengan negara lain. ${ }^{18}$ Ketentuan selanjutnya mengenai perjanjian internasional ini telah diatur dalam UU Perjanjian Internasional.

Namun kehadiran Undang-Undang Perjanjian Internasional tidak secara tegas menjelaskan kedudukan perjanjian internasional dalam sistem perundang-undangan, namun hanya menyatakan bahwa perjanjian internasional disahkan dengan undang-undang atau keputusan presiden tanpa lebih lanjut menjelaskan apa arti dan konsekuensinya bagi perundang-undangan Indonesia. Dalam tataran praktis, dikalangan pemerintah dan opini publik berkembang berbagai alur pikiran yang dapat dipetakan sebagai berikut:1) Alur pikiran yang menempatkan perjanjian internasional yang telah disahkan (diratifikasi) sebagai bagian dari hukum nasional; 2) Alur pikiran yang mengharuskan adanya legislasi nasional tersendiri untuk mengimplementasikan suatu perjanjian internasional yang telah disahkan. ${ }^{19}$ Sejalan dengan alur pikiran diatas, penulis melihat bahwa argumentasi pada alur pikiran yang pertama dapat penulis dukung dengan melihat praktek pengujian konstitusional yang dilakukan oleh Mahkamah

\footnotetext{
16 Ibid, h. 95.

7 Alma Manuputy, et.al., Op.Cit., h. 171.

Ibid, h. 172.

9 Damos Dumoli Agusman, Op.Cit., h. 96.
} 
Konstitusi, misalnya pada kasus pengujian konstitusional terhadap UU pengesahan perjanjian internasional yaitu UU Nomor 38 Tahun 2008 tentang PengesahanCharter of the Association of Southeast Asian Nations (Piagam Perhimpunan Bangsa-Bangsa Asia Tenggara). ${ }^{20}$ Sedangkan alur pikiran kedua dapat pula dibenarkan dengan argumentasi bahwa pemberlakuan perjanjian internasional ke dalam hukum nasional Indonesia tidak serta merta. Undang-Undang Pengesahan Perjanjian Internasional tersebut tidak serta merta menjadi perjanjian internasional menjadi hukum nasional Indonesia, UU ratifikasi hanya menjadikan Indonesia sebagai negara terikat terhadap perjanjian internasional tersebut. Untuk perjanjian internasional tersebut berlaku perlu dibuat UU yang lebih spesifik mengenai perjanjian internasional yang diratifikasi. ${ }^{21}$ Sejalan dengan hal ini, Hamdan Zoelva menyatakan bahwa pelaksanaan dari hak dan kewajiban yang ditentukan dalam perjanjian internasional tidak serta merta berlaku bagi setiap warga negara sebagaimana halnya ketentuan undang-undang pada umumnya, tetapi harus diimplementasikan lebih lanjut dalam undang-undang atau bentuk kebijakan lainnya. ${ }^{22}$

Ketidakjelasan pendirian terhadap aliran pikiran tersebut seharusnya dapat diatasi melalui penegasan dari konstitusi mengenai aliran atau doktrin yang dianut hukum Indonesia tentang hubungan hukum internasional dan hukum nasional. Jika tidak dalam konstitusi, maka hendaknya peraturan perundangan tentang perjanjian internasional memberikan kaidah yang tegas mengenai status hukum perjanjian internasional dalam hukum nasional.

Bagi masyarakat internasional pada umumnya ataupun bagi negara-negara peserta lainnya tentulah akan lebih baik jika perjanjian internasional itu sendirilah yang harus diutamakan dalam penerapannya, demi terwujudnya tertib masyarakat internasional pada umumnya. Dapat dibayangkan akan timbul anarkhi internasional, yang tentu saja akan merugikan semua pihak jika masing-masing negara peserta menolak atau melanggar ketentuan perjanjian internasional atau gagal melaksanakan kewajiban internasional yang berasal dari suatu perjanjian internasional, atau dengan alasan bahwa perjanjian itu bertentangan dengan hukum atau peraturan perundangundangan nasionalnya. Hal ini sekaligus juga akan merendahkan nilai-nilai dan tujuan luhur dari perjanjian-perjanjian internasional pada umumnya. ${ }^{23}$

Pasal 27 Konvensi Wina menyatakan bahwa: A party may not invoke the provisions of its internal law as justification for its failure to perform a treaty. This rule is without prejudice to article 46. Ketentuan ini harusnya dapat dimengerti sebab jika masing-masing negara dibenarkan mengemukakan alasan berdasarkan hukum nasional, maka akibatnya akan sangat besar kemungkinan akan terjadinya penyalahgunaan atas alasan berdasarkan hukum nasional, misalnya akan menimbulkan ketidakpastian hukum yang amat besar.

\footnotetext{
20 Lihat Putusan Mahkamah Konstitusi Nomor 33/PUU-IX/2011.

21 Dina Sunyowati, Enny Narwati, dan Lina Hastuti, Buku Ajar: Hukum Internasional, Pusat Penerbitan dan Percetakan Unair (AUP), Surabaya, 2011, h. 46.

22 Lihat Dissenting Opinion Hakim Hamdan Zoelva, Putusan Mahkamah Konstitusi Nomor 33/PUUIX/2011, mengenai Pengujian Undang-Undang Nomor 38 Tahun 2008 tentang Pengesahan Charter of the Association of Southeast Asian Nations (Piagam Perhimpunan bangsa-Bangsa Asia Tenggara).

23 I Wayan Parthiana, Hukum Perjanjian Internasional Bagian 2, Mandar Maju, Bandung, 2005, h. 276.
} 
Ketentuan Pasal 27 ini haruslah dibedakan dengan ketentuan Pasal 46 yang mengatur tentang ketidakabsahan suatu perjanjian internasional berdasarkan atas alasan hukum nasional. Menurut Pasal 46, suatu negara tidak diperkenankan mengklaim bahwa suatu perjanjian internasional merupakan perjanjian yang tidak sah dan kerena itu harus dibatalkan disebabkan karena persetujuannya untuk terikat pada perjanjian internasional itu sendiri merupakan pelanggaran atas ketentuan hukum nasionalnya, tegasnya hukum nasionalnya yang mengatur tentang kewenangan untuk membuat maupun menyatakan persetujuan untuk terikat (meratifikasi) pada suatu perjanjian internasional. Pasal 46 ini mempersoalkan keabsahan atas keterikatan suatu negara pada suatu perjanjian internasional dimana pada waktu pembuatan hingga perjanjian itu mulai berlaku atau mengikat ternyata bertentangan atau merupakan pelanggaran atas ketentuan hukum nasionalnya. Sedangkan Pasal 27 berkenaan dengan kegagalan negara yang bersangkutan melaksanakan ketentuan perjanjian disebabkan oleh hukum atau peraturan perundang-undangan nasional negara itu sendiri.

Menurut penulis, Pasal 46 Konvensi Wina tersebut dapat dikaitkan dengan sebabsebab tidak sahnya suatu perjanjian internasional yang diistilahkan dengan Irregularities Formal, yaitu tidak sahnya suatu perjanjian disebabkan oleh bentuk perjanjian yang salah atau bertentangan (melanggar) ketentuan hukum nasional. Hal yang dimaksud dengan bertentangan dengan ketentuan hukum nasional dalam bahasan ini, dibatasi hanya jika pelanggaran terhadap ketentuan hukum nasional tersebut dilakukan dengan unsur secara sengaja, dengan itikad buruk, terang-terangan dan melanggar ketentuan hukum nasional yang penting dan mendasar. Suatu negara terikat dalam perjanjian internasional tersebut dapat mengatakan tidak sah selama keempat umsur tersebut terpenuhi, begitupun sebaliknya. ${ }^{24}$

\section{Ratifikasi (Ratification)}

Menurut Konvensi Wina, ratifikasi adalah salah satu cara untuk mengikatkan diri pada suatu perjanjian ${ }^{25}$ dan lazimnya selalu didahului dengan penandatanganan. Perjanjian yang berlaku tanpa melalui persyaratan ratifikasi biasanya mulai berlaku pada saat penandatanganan dan dalam berbagai perjanjian selalu dirumuskan sebagai berikut: "The present agreement shall come into force on the date of its signing", ${ }^{26}$

Secara teori, ratifikasi adalah persetujuan oleh kepala negara atau kepala pemerintahan dari negara penandatanganan yang dibubuhkan pada traktat itu oleh wkail-wakil yang berkuasa penuh yang telah diangkat sebagaimana mestinya. Namun, dalam praktek modern ratifikasi lebih penting daripada sekedar konfirmasi saja, yang dianggap merupakan pernyataan resmi oleh suatu negara tentang persetujuannya untuk terikat oleh traktat. Ratifikasi tidak dianggap mempunyai akibat berlaku surut, dengan maksud mengikatkan traktat itu sejak dari tanggal penandatanganan. Pasal 14 Konvensi Wina menentukan bahwa persetujuan suatu negara

\footnotetext{
24 Aktieva Tri Tjitrawati dan Jani Purnawanty, Op.Cit., h. 112.

25 Lihat Pasal 14 Konvensi Wina 1969 tentang Hukum Perjanjian Internasional.

26 Damos Dumoli Agusman, Op.Cit., h. 58.
} 
untuk terikat oleh suatu traktat ditegaskan melalui ratifikasi apabila: ${ }^{27}$ a) Traktat itu secara tegas menentukan demikian; b) Negara-negara yang merundingkannya menyepakati bahwa ratifikasi diperlukan; c) Traktat itu ditandatangani tunduk kepada ratifikasi; d) Kehendak untuk menandatangani tunduk kepada ratifikasi tampak dari Kuasa Penuh atau secara tegas dinyatakan selama berlangsungnya perundingan-perundingan.

Lord Mc Nair, menyatakan bahwa ratifikasi mempunyai arti kegunaan secara berbedabeda. Ratifikasi dapat diartikan sebagai: a) The act of the appropriate organ of the state be it the sovereign or a presiden or a federal council which signifies the willingness of a state to be bound by a treaty; This is sometimes called ratification in the constitutional sense; $b$ ) The international procedure where by a treaty inters into force, namely the formal exchange or deposit of the instrument or ratification, ${ }^{28}$ c) The actual document, sealed or otherwise authenticated. Where by a state expresses its willingness to be bound by a treaty; d) Lossely and popularly, the approval of legislature or other state organ whose approval may be necessary; this is an unfortunate use of the word and should be avoided. ${ }^{29}$

Konvensi Wina tidak mengatur mengenai persyaratan hukum nasional sebelum ratifikasi. Secara garis besar, terdapat dua tradisi yang berbeda telah muncul di dunia Barat. Salah satu tradisi ditandai oleh 'Westminster practice' (Inggris, Australia, Kanada, Israel) di mana pembuatan perjanjian dilakukan di bawah hak prerogatif kerajaan tanpa perlu persetujuan parlemen. Dalam hal ini, eksekutif yang bertanggung jawab secara politik melalui kekuatan pengawasan, konsultasi atau hak atas informasi. Tradisi lainnya berakar kuat di Eropa Kontinental dan Amerika Serikat di mana persetujuan parlemen harus diadakan dalam sejumlah perjanjian tertentu. ${ }^{30}$ Pada umumnya, ratifikasi perjanjian internasional diwujudkan melalui dua tahapan, yaitu tahapan Hukum Nasional dan Tahapan Hukum Internasional. Dalam sistem pemerintahan yang demokratis, pengesahan perjanjian Internasional oleh pemerintah baru dapat dilaksanakan setelah mendapat persetujuan dari parlemen. Setelah perjanjian Internasional mendapat pengesahan, kemudian dimuat dalam dokumen ratifikasi. Hanya setelah kedua tahapan ini selesai diwujudkan, baru perjanjian internasional mengikat negara-negara. ${ }^{31}$

27 J. G. Starke, Op.Cit., h. 601-602

28 Poin b dan c berdasarkan pendapat Lord Mc Nair dalam mengartikan ratifikasi tersebut mempunyai perbedaan dengan makna rumusan Pasal 2 (1) b Konvensi Wina. Konvensi Wina menekankan segi perbuatan internasional, sedangkan Lord Mc Nair melihat ratifikasi sebagai prosedur internasional yang diperlukan agar sebuah perjanjian internasional berlaku (enter into force). Secara substansial Konvensi Wina memang mencantumkan ratifikasi sebagai salah satu cara negara menyatakan maksud untuk terikat kepada sebuah perjanjian internasional. Namun secara detail bagaimana ratifikasi tersebut harus dilakukan oleh sebuah negara, Konvensi Wina tidak mengatur. Jika apa yang dinyatakan oleh Lord Mc Nair bahwa ratifikasi adalah prosedur internasional diartikan dalam pengertian prosedur yang lengkap dan diatur oleh hukum internasional, maka dalam praktek tidak pernah terdapat suatu prosedur yang demikian diatur dalam hukum internasional. Kenyataannya prosedur ratifikasi ditentukan oleh hukum nasional negara sesuai dengan konstitusi masing-masing. Lihat, Ibid, h. 34.

29 Harjono, "Ratifikasi Perjanjian Internasional", Yuridika-Majalah Fakultas Hukum Unair, No. 4 Th. VIII, Agustus, 1993, h. 33.

30 Oliver Dorr dan Kristen Schmalenbach, Op.Cit., h. 186.

31 D. Sidik Suraputra, Ratifikasi Perjanjian Internasional Menurut Tiga Undang-Undang Dasar Indonesia, Hukum dan Pembangunan, No. 3 Th. XX, Juni, 1990,h. 217-218. 
Kesalahpahaman yang paling umum tentang ratifikasi adalah bahwa ratifikasi dianggap sebagai proses konstitusional. Padahal defenisi perjanjian internasional dalam konvensi Wina sudah sangat jelas, bahwa hal itu adalah perbuatan internasionalyang dilakukan dalam lingkupinternasional. Meskipun persetujuan parlemen perjanjian mungkin diperlukan -dimana hal ini terkadang menyesatkan karena disebut sebagai pengesahan- namun hal tersebut sesungguhnya proses yang sangat berbeda. Ratifikasi terdiri dari; Instrument of ratification oleh pemerintah/eksekutif baik exchange for the instrument of ratification dalam hal perjanjian bilateral, maupun dengan penyimpanan ratifikasi (depository) dalam hal perjanjian multilateral. ${ }^{32}$

Mengingat istilah ratifikasi yang dikenal dalam hukum internasional telah berinteraksi dengan prosedur nasional ketatanegaraan, maka baik teori maupun praktek negara melihat adanya kebutuhan untuk mengartikan ratifikasi perjanjian internasional dari dua perspektif prosedur yang terpisah namun terkait, yaitu prosedur internal dan ekseternal. Dari perspektif prosedur internal, ratifikasi perjanjian internasional adalah masalah hukum tata negara, yaitu hukum nasional Indonesia yang mengatur tentang kewenangan eksekutif dan legislatif dalam pembuatan perjanjian internasional serta mengatur produk hukum apa yang harus dikeluarkan untuk menjadi dasar bagi Indonesia melakukan prosedur eksternal. ${ }^{33}$ Sedangkan dari perspektif prosedur eksternal maka ratifikasi perjanjian adalah the international act so named whereby a State establishes on the international plane its consent to be bound by a treaty yang validitasnya diatur oleh hukum perjanjian internasional.

Para perumus Konvensi Wina 1969 menyadari adanya perbedaan ini dan bahkan mengakui bahwa perspektif ini selalu membingungkan. Komisi Hukum Internasional (ILC) dalam perumusan Konvensi ini secara tegas menyatakan bahwa: ${ }^{34}$

Since it is clear that there is some tendency for the international and internal procedures to be confused and since it is only international prosedures which are relevant to international law of treaties, the Comission thought it desirable in the definition to lay haeavy emphasis on the fact that it is purely the internationak act to which the terms ratification relate in the present article.

Selanjutnya mengenai ratifikasi di Indonesia, oleh Damos Dumoli Agusman, menyatakan bahwa:Berbagai literatur di Indonesia menjelaskan kedua jenis perjanjian berdasarkan tahapan pembuatannya, yaitu: 1) Perjanjian yang dibuat tiga tahap, yaitu perundingan, penandatanganan, dan ratifikasi; 3) Perjanjian yang dibuat dua tahap, yaitu perundingan dan penandatanganan. ${ }^{35}$

Berdasarkan rumusan di atas maka ratifikasi adalah perbuatan hukum lebih lanjut suatu negara guna mengonfirmasi perbuatan penandatanganan yang mendahuluinya. Konvensi juga mengenal cara pengikatan lain seperti aksesi (accession) yang tidak didahului dengan penandatanganan, melainkan didahului dengan adanya suatu perjanjian yang sudah terbentuk dan terbuka bagi negara yang tidak menandatangani untuk turut serta. UU Perjanjian

\footnotetext{
32 Anthony Aust, Modern Treaty Law and Practice, Op.Cit., h. 81.

33 Damos Dumoli Agusman. Op.Cit., h. 70.

34 Ibid.

35 Ibid.
} 
Internasional menerjemahkan ratifikasi dan aksesi menjadi satu istilah yaitu pengesahan. ${ }^{36}$ Kebingungan yang menyamakan istilah ratifikasi dari dimensi internasional dengan dimensi nasional seperti yang telah dijelaskan sebelumnya, juga terjadi di Indonesia. Praktik hukum Indonesia sejak kemerdekaan sampai dengan terbentuknya UU Nomor 24 tahun 2000 tentang Perjanjian Internasional tidak luput dari persoalan pencampuradukan ini.

Ratifikasi tidak sama dengan aksesi, namun setara dengan tanda tangan untuk ratifikasi. Aturan tentang penyerahan instrumen ratifikasi (atau penerimaan atau persetujuan) berlaku juga untuk instrumen aksesi, dan, kecuali perjanjian menyediakan sebaliknya, aksesi memiliki efek yang sama seperti ratifikasi. ${ }^{37}$ Seperti hak untuk menandatangani, hak untuk mengaksesi dapat dibatasi pada kategori tertentu atau kategori negara tertentu, dan dapat dibuat sesuai dengan kondisi atau persetujuan. ${ }^{38}$

\section{Konsep Entry into Force dalam Perjanjian Internasional}

Setelah memenuhi syarat ratifikasi atau dengan cara lain sesuai kesepakatan dalam perjanjian, maka masalah selanjutnya adalah kapan saat mulai berlakunya suatu perjanjian internasional itu sendiri. Terdapat berbagai macam tentang saat mulai berlakunya suatu perjanjian internasional, sesuai dengan bentuk dan macam perjanjian internasional itu sendiri. Pada hakekatnya, saat mulai berlakunya suatu perjanjian internasional sangat bergantung pada kesepakatan dari para pihak yang mengadakan perundingan dan merumuskan naskah perjanjian itu sendiri. ${ }^{39}$ Mengutip Michael Akehurst, bahwa; A treaty normally enters into force as soon as all the negotiating states have expressed their consent to be bound by it. But the negotiating states are always free to depart from this general rules, by inserting an appropriate provision in the treaty itself. ${ }^{40}$ Patut diingat, bahwa saat mulai berlakunya perjanjian merupakan saat yang sangat penting bagi semua pihak, sebab pada saat itulah suatu perjanjian berubah statusnya menjadi kaidah hukum positif yang sekaligus juga melahirkan hak dan kewajiban hukum bagi para pihak yang terikat pada perjanjian itu sendiri. ${ }^{41}$

Sebagai penegasan kembali, bahwa berdasarkan Konvensi Wina, dibedakan antara "expressing consent to be bound by a treaty" yang diatur dalam Pasal 11 dan sebuah perjanjian internasional yang mempunyai daya berlaku (entry into force), yang diatur dalam Pasal 24. Dengan adanya pengertian yang berbeda dapat menimbulkan konsekuensi bahwa adanya ratifikasi tidak selalu bertepatan waktu dengan mulainya perjanjian internasional mempunyai daya berlaku. ${ }^{42}$ Sebuah perjanjian masuk berlaku dengan cara tertentu dan pada tanggal yang ditetapkan dalam perjanjian atau sesuai persetujuan negara negosiasi (Pasal 24 (1)).

\footnotetext{
36 Ibid.

37 Anthony Aust, Modern Treaty Law and Practice, Op.Cit., h. 90.

38 Ibid, h. 89.

39 I Wayan Parthiana, Hukum Perjanjian Internasional Bagian 1, Op.Cit., h. 123.

40 Michael Akehurst, Op.Cit., h. 126.

41 I Wayan Parthiana, Hukum Perjanjian Internasional Bagian 1, Op.Cit., h. 125.

42 Harjono, "Ratifikasi Perjanjian Internasional", Op.Cit., h. 35.
} 
Pada Pasal 25 Ayat (1) Konvensi Wina juga mengatur mengenai provisional application atau pemberlakuan sementara atas suatu perjanjian internasional. Hal ini dimaksudkan bahwa suatu perjanjian internasional atau sebagian dari suatu perjanjian internasional diberlakukan atau diterapkan untuk sementara waktu sambil menunggu mulai berlakunya perjanjian tersebut, jika; perjanjian itu sendiri yang mengatur hal demikian; atau negara-negara negosiasi memiliki cara-cara lain yang telah disepakati. Dari ketentuan ini, maka pengaturan pemberlakuan sementara sebuah perjanjian internasional sepenuhnya berdasarkan kesepakatan negara-negara yang membuatnya.

Sedangkan pada Pasal 25 Ayat (2) dikatakan bahwa kecuali perjanjian menentukan sebaliknya, atau negara-negara yang melakukan perundingan telah menyepakati sebaliknya, pemberlakuan sementara atas suatu perjanjian atau sebagian dari perjanjian dalam hubungannya dengan suatu negara harus diakhiri, jika negara yang bersangkutan memberitahukan kepada negara pihak lainnya mengenai maksudnya untuk tidak menjadi pihak pada perjanjian itu. ${ }^{43}$ Ketentuan ayat 2 ini disetujui pada perundingan Konvensi Wina dari proposal oleh Belgium, Hungary, dan Poland, yang menyatakan: ${ }^{44}$ providing that the provisional application of a treaty with respect to a state is terminated if that states notifies the other states between which the treaty is being applied provisionally of its intention not to become a party.

Berdasarkan penjelasan di atas, maka setelah seluruh proses pembuatan traktat tersebut dilakukan, traktat atau perjanjian internasional tersebut memiliki daya mengikat yang dipatuhi oleh negara peserta berdasarkan prinsip pacta sunt servanda. Terkait dengan ketentuan mengenai langkah penandatanganan, aturan di Indonesia berdasarkan penjelasan pasal 6 UU Perjanjian Internasional kemudian melihat bahwa pada dasarnya penandatanganan merupakan tahap akhir dalam perundingan bilateral untuk melegalisasi suatu naskah perjanjian internasional yang telah disepakati oleh kedua belah pihak. Sedangkan untuk perjanjian internasional yang multilateral, penandatanganan perjanjian internasional bukan merupakan pengikatan diri sebagai negara pihak. Keterikatan terhadap perjanjian internasional dapat dilakukan melalui pengesahan (ratification/accession/acceptance/approval). Selanjutnya, penjelasan ayat (2) menegaskan kembali bahwa penandatanganan suatu perjanjian internasional tidak sekaligus diartikan sebagai pengikatan diri pada perjanjian tersebut. Penandatanganan suatu perjanjian internasional yang memerlukan pengesahan, tidak mengikat pada pihak sebelum perjanjian tersebut disahkan.

\section{Invalidity dan Termination Perjanjian Internasional}

Konvensi Wina mengatur tentang Invalidity (ketidakabsahan), dan Termination (pengakhiran) perjanjian internasional. Terminologi tersebut adalah dua hal yang berbeda dan mempunyai akibat hukum masing-masing. Ketidakabsahan sebuah perjanjian internasional

43 I Wayan Parthiana, Hukum Perjanjian Internasional Bagian 1, Op.Cit., h. 128.

44 Sinclair, I. M., The Vienna Convention on The Law of Treaties, Manchester University Press, Manchester, 1973, h. 52. 
diatur dalam Pasal 46-52 dan pengakhiran atau berakhirnya suatu perjanjian internasional diatur dalam Pasal 54-56, sedangkan implikasi atau konsekuensinya diatur dalam Pasal 69-72.

Secara umum, suatu perjanjian internasional dinyatakan tidak sah adalah keseluruhan dari ketentuannya. Hal ini ditegaskan dalam Pasal 44 Ayat (2) bahwa alasan untuk menyatakan suatu perjanjian internasional tidak sah sebagaimana diakui dalam konvensi Wina ini hanya dapat dikemukakan berkenaan dengan keseluruhan ketentuannya. Ketidaksahan atas keseluruhan ketentuan perjanjian akan lebih muda untuk dipastikan, apabila keseluruhan ketentuan perjanjian itu merupakan suatu kesatuan utuh yang tidak dapat dipisahkan antara satu dengan lainnya ataupun antara bagian yang satu dengan bagian yang lainnya. Namun demikian, pada ayat 2 masih membuka pengecualian, yakni dimungkinkan adanya ketidaksahan atas sebagian atau beberapa ketentuannya. Pengecualian itu ditegaskan lebih lanjut dalam Pasal 44 Ayat 3, 4, 5 dan Pasal 60. Ayat 3 menegaskan tentang pernyataan tidak sahnya suatu perjanjian internasional hanya atas sebagian dari perjanjian itu sendiri atau atas ketentuan-ketentuan tertentu dari perjanjian itu, apabila: 1) Ketentuan demikian itu dapat dipisahkan dari keseluruhan perjanjian berkaitan dengan penerapannya; 2) Hal itu tampak dari perjanjian tersebut atau ditentukan sebaliknya, bahwa penerimaan atas ketentuan tersebut bukanlah merupakan basis atau dasar yang esensial dari persetujuan pihak lain atau para pihak untuk menyatakan persetujuan terikat pada perjanjian itu sebagai suatu keseluruhan; 3) Kesinambungan berlakunya ketentuan perjanjian yang masih ada atau masih berlaku itu tidak akan menimbulkan ketidakadilan ataupun ketimpangan. ${ }^{45}$

Oleh karena itu, setiap perjanjianinternasional yang memenuhi syarat-syarat ketidaksahan yang sesuai dengan syarat-syarat yang ada menurut Konvensi Wina, tidak mempunyai akibat hukum, dengan kata lain perjanjian tersebut adalah batal seperti yang tersebut dalam pasal 69 ayat 1 Konvensi Wina. Bersamaan dengan hal tersebut, diatur pula mengenai pengakhiran atas eksistensi suatu perjanjian internasional. Pasal 42 ayat 2 menegaskan, bahwa tentang pengakhiran suatu perjanjian internasional pertama-tama harus dilihat pada bagaimana pengaturannya di dalam perjanjian internasional itu sendiri. Sedangkan jika tidak ada pengaturannya, pengakhiran itu dilakukan dengan mengikuti ketentuan-ketentuan Konvensi. Padahal pasal 54 yang secara khusus mengatur tentang pengakhiran -dan juga penundaan- suatu perjanjian internasional, menyatakan bahwa perngakhiran suatu perjanjian internasional dapat dilakukan sesuai dengan ketentuan-ketentuan dari perjanjian itu sendiri, atau pengakhiran juga dapat dilakukan sesudah berkonsultasi dengan negara-negara peserta lainnya. ${ }^{46}$

\section{Hakikat Undang-Undang Pengesahan Perjanjian Internasional dalam Sistem Perun- dang-Undangan}

Berdasarkan penjelasan-penjelasan sebelumnya, maka penulis berpendapat bahwa sekiranya Undang-Undang Pengesahan Perjanjian Internasional menunjukkan sifatnya sebagai undang-undang formal yang dapat dianggap sebagai bentuk penyelenggaraan administrasi

\footnotetext{
45 I Wayan Parthiana, Hukum Perjanjian Internasional Bagian 2, Op.Cit., h. 425-426
}

46 I Wayan Parthiana, Hukum Perjanjian Internasional Bagian 2, Op.Cit., h. 
negara untuk memenuhi klausul "persetujuan DPR" dalam konstitusi. Hal ini dapat dikuatkan dengan argumentasi bahwa pada dasarnya Undang-Undang Pengesahan Perjanjian Internasional tersebut merupakan bentuk "pengesahan" dalam makna prosedur internal. Sekali lagi ditegaskan bahwa dengan adanya prosedur internal ini tidak secara serta merta membuat perjanjian internasional tersebut berlaku, melainkan harus melewati peosedur eksternal (dengan instrument of ratification) barulah perjanjian itu berlaku dan memiliki kekuatan mengikat. Hal ini juga menunjukkan bahwa materi muatan atau isi dari sebuah perjanjian internasional juga terikat pada hukum internasional. Sehingga menurut penulis materi muatannya tidak serta merta dapat diutak-atik melalui sistem hukum nasional.

Selain itu, materi normatif sebuah perjanjian internasional juga tidak serta merta berlaku. Undang-Undang Pengesahan Perjanjian Internasional tersebut tidak serta merta menjadi perjanjian internasional menjadi hukum nasional Indonesia, Undang-Undang Pengesahan Perjanjian Internasional hanya menjadikan Indonesia sebagai negara terikat terhadap perjanjian internasional tersebut. Untuk perjanjian internasional tersebut berlaku perlu dibuat UU yang lebih spesifik mengenai perjanjian internasional yang diratifikasi. ${ }^{47}$

Penegasan lain yang dapat penulis sandarkan yaitu dengan melihat sebuah prosedur pembuatan RUU Pengesahan Perjanjian Internasional menjadi UU, dimana dalam menanggapi naskah yang diajukan oleh pemerintah untuk dimintai persetujuannya, DPR tidak sebebas menanggapi sebuah rancangan undang-undang biasa, karena naskah yang dibahas tersebut sudah merupakan naskah yang disepakati bersama oleh wakil-wakil negara peserta bahkan mungkin sudah dilakukan autentikasi. Sehingga dengan begitu DPR terbatas hanya pada menyetujui RUU pengesahan ini untuk dilanjutkan oleh Pemerintah ke ranah prosedur eksternal yaitu ratifikasi ataukah tidak.

Bentuk undang-undang pengesahan ini memiliki karakter tersendiri yang telah dijelaskan secara implisit dari rangkaian pembahasan ini. Oleh karena itu, meskipun bentuknya sebagai UU namun hal ini harus dianggap sebagai UU formal yang dibentuk dalam rangka kehendak negara untuk mengikatkan diri pada sebuah perjanjian internasional. Materi normatif dalam Undang-Undang Pengesahan Perjanjian Internasional tunduk pada hukum internasional yang telah dibuat dan disepakati oleh para negara pembuatnya. Pasal 2 Konvensi Wina telah menegaskan bahwa perjanjian internasional itu "governed by international law." Sehingga penekanannya harus berada pada ranah hukum internasional, harus ada niat untuk menciptakan kewajiban yang tunduk pada hukum internasional.

\section{Pengujian Konstitusional Undang-Undang Pengesahan Perjanjian Internasional}

Berdasarkan Pasal 24C Ayat (1), salah satu kewenangan Mahkamah Konstitusi yaitu melakukan pengujian undang-undang terhadap Undang-Undang Dasar. Namun pemahaman terhadap undang-undang sebagai objek pengujian Mahkamah Konstitusi telah berkembang

\footnotetext{
47 Dina Sunyowati, Enny Narwati dan Lina Hastuti, Op.Cit., h. 46.
} 
seperti yang dapat dilihat pada beberapa putusannya, misalnya pengujian terhadap Peraturan Pemerintah sebagai Pengganti Undang-Undang (selanjutnya disingkat Perpu), ${ }^{48}$ dan pengujian terhadap lampiran undang-undang. ${ }^{49}$

Terkait dengan fokus penulisan ini, Undang-Undang Pengesahan Perjanjian Internasional, merupakan salah satu bentuk dari format undang-undang yang materi normatifnya tidak terdapat dalam undang-undang itu sendiri, melainkan terdapat dalam lampirannya. Undangundang hanya memuat pasal pengesahan saja sedangkan materi normatifnya yaitu Perjanjian internasional itu sendiri berada pada lampiran undang-undang pengesahan tersebut.

Di satu sisi, lampiran undang-undang adalah bagian yang tidak terpisahkan dari undangundang itu sendiri. ${ }^{50}$ Sehingga dengan demikian secara praktis dapat dikatakan bahwa pengujian undang-undang terhadap UUD dapat dilakukan untuk menilai konstitusionalitasnya. Namun disisi lain, jika dilakukan pengujian materi normatifnya (yaitu perjanjian internasional), maka perjanjian internasional yang otentik itu sendiri merupakan produk yang tunduk pada hukum internasional ${ }^{51}$ yang oleh Indonesia tidak mungkin ditolak sebagian dan diterima sebagian lainnya setelah dilakukan prosedur ratifikasi oleh Indonesia. ${ }^{52}$ Oleh karena itu dapat dilihat terjadinya konflik norma atau pertentangan antara hukum internasional dan hukum nasional dalam kaitan terhadap pengujian Undang-Undang Pengesahan Perjanjian Internasional ini.

Konflik ini wajar terjadi karena pengambilan bentuk "persetujuan DPR" terhadap perjanjian internasional melalui format undang-undang. Dengan hadirnya sebagai UU, umumnya memiliki konsekuensi sebagai objek pengujian oleh MK. Namun Harjono dalam disertasinya mengungkapkan bahwa seharusnya ada 'imunitas' atau pengecualian terhadap Keputusan Presiden (pada masa orde baru dimana masih terjadinya executive heavy, perjanjian internasional lebih banyak dituangkan dalam bentuk Keputusan Presiden dan memang gagasan mengenai constitutional review belum diwujudkan karena lembaga Mahkamah Konstitusi lahir pada tahun 2003 setelah diamanahkan oleh amandemen UUD 1945) yang berisi perjanjian internasional sebagai objek pengujian materiil oleh Mahkmah Agung (MA). ${ }^{53}$ Imunitas dalam konteks pengecualian terhadap Keputusan Presiden yang materinya berisi perjanjian internasional

48 Dalam hal ini, secara substantif atau dari segi isi muatannya, Perpu sebenarnya adalah undang-undang. Akan tetapi, situasi yang dihadapi sedemikian rupa (hal ikhwal kegentingan yang memaksa), sehingga materi norma yang perlu diatur itu tidak mungkin dituangkan dalam bentuk undang-undang. Namun berdasarkan Putusan Mahkamah Konstitusi Nomor 138/PUU-VII/2009, Mahkamah Konstitusi berwenang melakukan pengujan dengan alasan bahwa oleh karena dapat menimbulkan norma hukum yang kekuatan mengikatnya sama dengan undangundang maka terhadap norma yang terdapat dalam Perppu tersebut Mahkamah dapat menguji apakah bertentangan secara materiil dengan UUD 1945. Lihat Jimly Asshiddiqie, Hukum Acara Pengujian Undang-Undang, Op.Cit., h. 43., Lihat Putusan Mahkamah Konstitusi Nomor 138/PUU-VII/2009.

49 Undang-Undang tentang APBN dan Undang-Undang Pengesahan Perjanjian Internasional merupakan bentuk Undang-Undang yang materi muatannya berada pada lampiran UU tersebut. Namun dalam penelitian ini, fokus penulis berada pada bentuk Undang-Undang Pengesahan Perjanjian Internasional.

50 Lihat UU Nomor 12 Tahun 2011 tentang Pembentukan Peraturan Perundang-Undangan.

51 Bahwa suatu perjanjian internasional harus dimaksudkan governed by international law berdasarkan defenisi perjanjian internasional menurut Konvensi Wina.

52 Jimly Asshiddiqie, Hukum Acara Pengujian Undang-Undang, Op.Cit., h. 49.

53 Harjono, “Aspek-Aspek Yuridis Pembuatan Perjanjian Internasional dalam Sistem UUD 1945”, Disertasi, Fakultas Hukum Universitas Airlangga, Surabaya, 1994, h. 146. 
dari sasaran pengujian oleh Mahkamah Agung mempunyai tujuan untuk memberikan kepastian hukum kekuatan mengikat perjanjian internasional, dengan demikian secara yuridis dapat mengangkat citra hukum Indonesia di dunia Internasional karena sistem hukum Indonesia memberi jaminan kepastian pada perjanjian internasional yang dibuat oleh Presiden. ${ }^{54}$ Uraian pembahasan pengujian oleh MA terhadap Keputusan Presiden oleh Harjono ini lebih kurang dapat disamakan dengan pengujian undang-undang oleh MK. Poin utama yang ingin penulis tekankan adalah pada hakikat pengujiannya, terlepas dari bentuk Keputusan Presiden oleh MA maupun Undang-Undang oleh MK seperti pada masa sekarang.

Sesungguhnya menurut penulis sinkronisasi preventif yang dimaksudkan di atas dapat dilakukan melalui upaya-upaya seperti mengadakan reservasi ${ }^{55}$. Secara hukum internasional, reservasi terhadap beberapa ketentuan perjanjian internasional dapat dilakukan. Sehingga kecermatan pemerintah dalam membuat perjanjian internasional sangat diperlukan. Apabila sebuah ketentuan dianggap akan bertentangan dengan hukum nasional maka bisa dilakukan reservasi saja sebagai bentuk preventif agar kelak ketentuan tersebut dikecualikan kepada Indonesia dan tidak berlaku dalam hukum nasional. Tidak hanya mekanisme reservasi yang bisa dilakukan sebagai upaya preventif, misalnya saja di Belanda, pada saat pemerintah pada dalam tahap negosiasi atau perunding untuk membuat sebuah perjanjian internasional, parlemen juga dikirimkan salinan perjanjian (draft treaty) agar bisa ikut serta memberikan pertimbangan sehingga sebelum pemerintah mengambil keputusan, pertimbangan parlemen telah diberikan sehingga diharapkan tidak ada lagi pertentangan dengan hukum nasional. ${ }^{56}$

Pertanyaan mengenai pengujian terhadap bentuk hukum yang mengesahkan perjanjian internasional sudah dipikirkan sejak dulu. Ketentuan hukum perjanjian internasional dalam Konvensi Wina 1969 telah menentukan bahwa sebuah perjanjian internasional tanpa mempertimbangkan bentuk hukum menurut hukum nasional, haruslah dianggap dibuat dengan itikad yang baik sehingga kewajiban setiap negara untuk tetap mematuhi perjanjian yang telah dibuatnya. Negara yang telah menyatakan terikat oleh perjanjian internasional tidak bebas lagi untuk menyatakan bahwa negara tersebut tidak dapat melaksanakan perjanjian yang telah dibuatnya karena bertentangan dengan hukum nasionalnya. Pasal 46 Konvensi Wina hanya memungkinkan alasan bahwa perjanjian internasional telah dibuat bertentangan dengan hukum nasional jika ternyata perjanjian tersebut secara nyata-nyata bertentangan dengan hukum yang sangat penting tentang kompetensi (kewenangan) untuk membuat perjanjian internasional, yang dimana hal ini penulis sandarkan pada maksud irregularities formal. Menguatnya alur pemikiran terhadap tidak dapat dilakukannya pengujian terhadap Undang-Undang Pengesahan

54 Ibid, h. 255.

55 Reservasi, yaitu pernyataan sepihak, bagaimanapun diungkapkan, yang dibuat oleh suatu negara, ketika menandatangani, menerima (accepting), menyetujui (approving), atau ikut serta (accending) pada suatu perjanjian, yang mana pihak tersebut mengakui atau meniadakan maupun merubah ketentuan-ketentuan tertentu suatu perjanjian dalam penerapannya bagi negara yang diwakilinya. Lihat Aktieva Tri Tjitrawati dan Jani Purnawanty, Op.Cit., h. 48.

56 Duncan B. Hollis, Merritt R. Blakesle dan L. Benjamin Ederington, Op.Cit., h. 488. 
Perjanjian Internasional juga terjadi akibat pemahaman mengenai kedudukan perjanjian internasional dalam sistem hukum Indonesia apakah berlaku secara serta merta atau butuh proses transformasi. Sekali lagi ini terjadi akibat ketidak jelasan aliran monoisme atau dualisme yang dianut oleh Indonesia. Pada beberapa kalangan akademisi menandakan bahwa Undang-Undang Pengesahan Perjanjian Internasional tidak serta merta berlaku melainkan membutuhkan proses legislasi nasional untuk membuatnya berlaku utuh dalam hukum nasional. Pada prinsipnya kekuatan mengikat suatu perjanjian hanya berakibat pada negara yang mengadakan perjanjian (contracting states), bukan pada warga negaranya. Sedangkan jika kebijakan berisi kesepakatan yang memengaruhi hak dan kewajiban warga negara di wilayah hukum negara peserta perjanjian, maka para pihak wajib mengambil beberapa langkah seperlunya menurut hukum nasionalnya sendiri dan kewajibannya itu harus sesuai dengan syarat-syarat kebijakan perjanjian. ${ }^{57}$ Maria Fairda dalam dissenting opinion nya terhadap pengujian undnag-undnag pengesahan perjanjian internasional tentang ASEAN Charter menegaskan bahwa hakikat Undang-Undang Pengesahan Perjanjian Internasional itu sendiri sebagai suatu peraturan perundang-undangan yang bukanlah substansinya bersifat normatif, yang adressat normanya dapat secara langsung ditujukan kapada setiap orang. ${ }^{58}$

Di sisi lain, praktek pengujian Undang-Undang Pengesahan Perjanjian Internasional yang dilakukan oleh $\mathrm{MK}^{59}$ ini menandakan dianutnya prinsip monoisme primat hukum nasional dimana materi perjanjian internasional dalam undang-undang pengesahan tersebut dapat langsung diuji karena dianggap langsung berlaku dengan undang-undang pengesahan tanpa dibutuhkannya undang-undang yang mentrasformasikan perjanjian internasional ke dalam hukum nasional. Pembahasan selanjutnya, penulis ingin mengangkat mengenai akar masalah terhadap pergeseran makna 'persetujuan' menjadi 'pengesahan' sehingga berdampak pada hakikat Undang-Undang Pengesahan Perjanjian Internasional. Telah dijelaskan sebelumnya bahwa pada awalnya, khususnya pada tataran norma, hukum tata negara Indonesia tidak bermaksud menyentuh permasalahan ratifikasi (dimensi internasional), melainkan hanya membatasi diri pada pengaturan nasional tentang perjanjian. Pendekatan ini tercermin pada rumusan Pasal 11 UUD 1945 yang menyebut bahwa "Presiden dengan persetujuan DPR membuat Perjanjian", dan sama sekali tidak menyebut ratifikasi sehingga tidak terjadi komplikasi pemahaman ratifikasi antara eksternal dan internal. Para ahli tata negara pada awalnya juga mengartikan ratifikasi sebagai konsepsi internasional dan bukan internal. ${ }^{60}$

Selanjutnya, Utrecht menjelaskan mekanisme Pasal 11 UUD 1945, yaitu suatu perjanjian internasional harus terlebih dahulu mendapat persetujuan DPR dan dituangkan dalam suatu undang-undang persetujuan (goedkeuringswet) yang bersifat undang-undang formal saja. Kemudian, setelah mendapat persetujuan DPR, Presiden melakukan pengesahan yang disebut

\footnotetext{
57 Aktieva Tri Tjitrawati dan Jani Purnawanty, op.Cit., h. 87.

58 Ibid.

59 Lihat Putusan Mahkamah Konstitusi Nomor 33/PUU-IX /2011

60 Damos Dumoli Agusman, Op.Cit., h. 74.
} 
dengan ratifikasi. Dari penjelasan ini, Utrecht membedakan secara tegas makna persetujuan DPR dan ratifikasi.Pada awalnya istilah "persetujuan" telah dilaksanakan secara konsisten dalam praktik, sehingga kaliamat yang digunakan untuk mencerminkan "persetujuan" ini selalu ditekankan pada undang-undang yang mengesahkannya, sehingga judul undang-undang pada umumnya berbunyi, sebagai contoh: Undang-Undang Republik Indonesia No. 4 Tahun 1951 tentang Memberikan Persetujuan kepada Perjanjian Pinjaman antara Pemerintah Kerajaan Nederland dan Pemerintah Republik Indonesia Serikat. ${ }^{61}$

Dalam perkembangannya, Undang-Undang No. 24 tahun 2000 tentang Perjanjian Internasional selanjutnya mengadopsi istilah "ratifikasi" dan sayangnya menerjemahkannya dengan istilah "pengesahan". Pengertian pengesahan dalam uraian pasal 9 (1) tidak lagi persis seperti yang dimaksud oleh definisi dan tanpa sengaja telah menggiring pemikiran banyak ahli dan publik Indonesia bahwa seolah pengikatan diri Indonesia ke suatu perjanjian (pengesahan) dilakukan dengan undang-undang atau Keputusan Presiden bukan dengan instrumen of ratification/accession/acceptance/approval yang diterbitkan oleh Menteri Luar Negeri. ${ }^{62}$

Oleh karena itu, hakikat Undang-Undang Pengesahan Perjanjian Internasional dapat dikatakan sebagai UU formal.UU pengesahan ini berfungsi sebagai bentuk persetujuan DPR terhadap suatu perjanjian internasional saja. Bentuk pengikatan diri secara internal ini diwujudkan dalam UU pengesahan, yang dengan dasar itu maka dapat diterbitkan instrument of ratification sebagai prosedur eksternal bahwa negara meratifikasi (dalam hal consent to be bound) yang akhirnya akan masuk pada tahap entry into forcedalam sebuah perjanjian internasional sesuai dengan kesepakatan.

Dikatakan sebagai UU formal maknanya adalah UU tersebut memenuhi kiteria sebagai wet in formale zijn, karena dibuat melalui prosedur pembentukan perundang-undangan yang sesuai dengan hukum nasional, tetapi tidak memenuhi wet in materiale zijn karena materi normatifnya adalah hasil pembentukan dari negara-negara pihak yang di buat governed by international law. Selain itu, dapat dilihat dalam prosedur pembuatan RUU Pengesahan Perjanjian Internasional menjadi UU, dimana dalam menanggapi naskah yang diajukan oleh pemerintah untuk dimintai persetujuannya, DPR tidak sebebas menanggapi sebuah rancangan undang-undang biasa, karena naskah yang dibahas tersebut sudah merupakan naskah yang disepakati bersama oleh wakil-wakil negara peserta bahkan mungkin sudah dilakukan autentikasi. Sehingga dengan begitu DPR terbatas hanya pada menyetujui RUU pengesahan ini untuk dilanjutkan oleh Pemerintah ke ranah prosedur eksternal yaitu ratifikasi ataukah tidak.

Meskipun demikian, hal ini sebenarnya masih debatable mengingat masih belum jelasnya kedudukan hukum internasional (secara sepesifik perjanjian internasional) yang dianut dalam sistem hukum Indonesia. Alur pemikiran yang masih berbeda-beda terjadi bergantung pada pemikiran mengenai doktrin mana yang di anut. Hal ini berbeda pada beberapa negara lain. Berdasarkan penjelasan mengenai kedudukan perjanjian internasional di beberapa negara, pada

${ }^{61}$ Ibid, h. 75 .

62 Ibid, h. 76. 
bab sebelumnya, ketentuan tentang perjanjian internasional yang dianut dalam hukum nasional telah jelas bahkan kerap kali memang dicantumkan dalam konstitusi sebagai bukti pentingnya pengaturan mengenai hukum internasional.

Kemudian, seperti yang diketahui bahwa UU pengesahan perjanjian internasional merupakan bentuk persetujuan DPR dalam hal perjanjian internasional yang disyaratkan harus dilakukan ratifikasi terhadapnya. Namun seperti yang telah dijelaskan pada bab sebelumnya, bahwa keterikatan negara pada sebuah perjanjian internasional tidak hanya melalui prosedur ratifikasi melainkan prosedur persetujuan (approval) atau penerimaan (acceptance) yang merupakan bentuk consent to be bound dengan cara yang lebih sederhana.

Istilah "penerimaan" (acceptance) ${ }^{63}$ yang dipakai dalam klausula, lambat laun telah masuk dalam terminologi traktat saat ini untuk menunjukkan tindakan menjadi peserta traktat dengan cara keikutsertaan yang bermacam-macam, sesuai dengan hukum tata negara nasional suatu negara. Tujuan utama klausula ini memang untuk memecahkan kesulitan-kesulitan yang kemungkinan menghalagi suatu negara yang timbul karena kaidah-kaidah konstitusi nasional mereka berkenaan dengan persetujuan traktat. Beberapa negara tidak menghendaki dipakainya istilah "ratifikasi", yang mungkin mensiratkan suatu kewajiban untuk mengajukan traktat kepada badan legislatif untuk disetujui atau melewati suatu prosedur konstitusional yang tidak dikehendaki. ${ }^{64}$ Namun bagaimanapun juga tetap berlaku sebagai perjanjian internasional yang setara dengan perjanjian internasional yang diratifikasi.

Dalam konteks acceptance tersebut dapat dilihat bahwa tidak terdapat pembedaan derajat antara perjanjian internasional melalui prosedur acceptance dengan perjanjian internasional yang di ratifikasi. Perjanjian internasional baik yang diratifikasi maupun melalui approval atau acceptance atau accession, atau cara-cara lain yang dibolehkan, memiliki kekuatan mengikat yang sama dengan perjanjian internasional yang diratifikasi yang dibentuk dalam Undang-Undang Pengesahan Perjanjian Internasional. Sekali lagi, sama-sama berlaku dan mengikat negara. Oleh karena itu, penulis menganggap bahwa kedudukan perjanjian internasional yang tidak dibuat dalam bentuk Undang-Undang Pengesahan Perjanjian Internasional tetapi mengikat dan berlaku kepada Indonesia.

Perjanjian melalui prosedur acceptance memang tidak bisa diuji karena tidak ada undang-undang sebagai bentuk hukumnya. Namun oleh karena itu juga maka tidak ada bedanya dengan perjanjian internasional yang diratifikasi yang berlaku dan mengikat, yang hanya saja kebetulan dibentuk dalam undang-undang pengesahan. Jangan dianggap bahwa harus dalam bentuk undang-undang barulah perjanjian internasional tersebut mengikat dan berlaku. Melainkan banyak cara sebuah negara dapat terikat dengan perjanjian internasional tanpa harus dengan ratifikasi. UU Perjanjian Internasional juga membenarkan hal ini, seperti melalui penandatanganan (signature). Uraian kompleksitas pengujian Undang-Undang Pengesahan Perjanjian Internasional ini penulis uraikan agar adanya perhatian khusus terhadap persoalan ini. Harus ada

${ }_{63}$ J.G. Starke, Op.Cit., h. 635.

64 Ibid, h. 599. 
pengkajian yang lebih mendalam untuk menentukan bagaimana konsep sistem hukum nasional Indonesia dalam menghadapi hal ini. Karena dengan dalil apapun juga, dalam satu sisi, prinsip supremasi konstitusi harus ditegakkan. Hanya saja harusnya terdapat mekanisme yang win-win solution agar dapat menghindari akibat hukum yang negatif dalam dunia internasional.

\section{Akibat Hukum Pengujian Undang-Undang Pengesahan Perjanjian Internasional}

Pengertian perjanjian internasional berdasarkan Konvensi Wina, merupakan "An international agreement concluded between states in written form and governed by international law, whether embodied in a single instrument or in two or more related instruments and whatever its particular designation." ${ }^{65}$ Makna governed by international law harus dilihat sebagai harus ada niat untuk menciptakan kewajiban yang tunduk pada hukum internasional. ${ }^{66}$ Sedangkan pelanggaran terhadap kewajiban akan memberikan konsekuensi tersendiri bagi negara. Sama halnya jika ternyata pengujian dilakukan dan kemudian dinyatakan batal, maka akibat hukum secara internasional pasti terjadi.

Putusan pengujian undang-undang oleh Mahkamah Konstitusi yang mencabut atau membatalkan berlakunya suatu pasal oleh suatu undang-undang menimbulkan dampak pada kondisi atau tatanan yang diatur melalui pasal atau undang-undang tersebut.Pasca putusan MK tentang pengujian suatu undang-undang yang mengabulkan permohonan, muncul masalah dalam menindaklanjutinya. Hingga saat ini, belum ada ketentuan yang mengatur tentang mekanisme tindak lanjut atau pelaksanaan putusan MK dalam proses legislasi. ${ }^{67}$

UU MK tidak mengatur tentang mekanisme tindak lanjut pengujian undang-undang. Dalam undang-undang tersebut hanya diatur kekuatan mengikat putusan pengujian undangundang. ${ }^{68}$ Sehingga hal ini seharusnya juga mendapat perhatian dalam konteks pengujian UndangUndang Pengesahan Perjanjian Internasional. Apabila pengujian yang dilakukan menyatakan batal maka bagaimana mekanisme tindak lanjut yang harus dilakukan oleh pemerintah untuk melaksanakan putusan tersebut, apakah serta merta harus melakukan penarikan diri atau adakah mekanisme lain yang dapat ditempuh untuk meminimalisir dampak negatif dalam pergaulan internasional.

Selain itu, praktek yang dilakukan oleh Mahkamah Konstitusi yaitu dapat menguji beberapa ketentuan/pasal materi normatif dari sebuah perjanjian internasional.Oleh karena itu, jika beberapa pasal yang dimohonkan diuji dan dinyatakan batal maka bagaimana untuk melaksanakan putusan tersebut. Negara Indonesia tidak memiliki wewenang penuh untuk meniadakan beberapa ketentuan saja tanpa persetujuan negara lain, sementara perjanjian internasional tunduk pada hukum internasional dimana Konvensi Wina menegaskan dalam Pasal 27 mengenai tidak dibolehkannya suatu negara gagal melaksanakan perjanjian internasional

65 Lihat Pasal 2 Konvensi Wina tentang Hukum Perjanjian Internasional

66 Anthony Aust, Modern Treaty Law and Practice, Op.Cit., h. 17.

67 M. Nur Sholikin, et.al., Pengujian Undang-Undang dan Proses Legislasi, Pusat Studi dan Kebijakan Indonesia, Jakarta, 2007, h. 23.

${ }^{68} \mathrm{Ibid}, \mathrm{h} .24$. 
karena alasan hukum nasionalnya. Selanjutnya, dengan tidak diterapkannya sebuah ketentuan yang berasal dari perjanjian internasional, maka sama akibatnya dengan penghentian perjanjian internasional tersebut.Sedangkan penghentian perjanjian internasional mempunyai tata cara tersendiri sebagaimana ditentukan dalam article 42 (2) Konvensi Wina 1969. ${ }^{69}$

Oleh karena itu, sejauh mana Mahkamah Konstitusi dapat menyatakannya tidak mempunyai kekuatan hukum mengikat sepanjang menyangkut materi tertentu saja tanpa berakibat kepada naskah perjanjian internasional itu secara keseluruhan. Karena pada dasarnya perjanjian internasional itu merupakan produk hukum internasional yang oleh Indonesia tidak mungkin ditolak sebagian dan diterima sebagian. ${ }^{70}$ Ketentuan tentang alasan pembatalan perjanjian internasional ini akibat hukum nasional hanya dapat disinggungkan dengan konsep irregularities formal. Tetapi sekali lagi, irrefularities formal ini terkait dengan bentuk kewenangan meratifikasi atau secara proseduralnya.

Selanjutnya, ketentuan mengenai batalnya perjanjian akibat pengujian yang dilakukan oleh MK bisa dilakukan melalui proses penarikan diri (apabila pada akhirnya diputusakan bahwa ketentuan itu secara keseluruhan dianggap inkonstitusional). Berakhirnya perjanjian internasional melalui penarikan diri dapat terjadi sesuai dengan ketentuan-ketentuan perjanjian, atau setiap waktu dengan persetujuan semua peserta setelah dilakukan konsultasi satu sama lain (Pasal 54). Apabila suatu negara ingin menarik diri dari sebuah traktat, maka biasanya dilakukan dengan cara memberitahukan pengakhiran itu atau dengan tindakan denunsiasi. Istilah denunsiasi (denunciation) menunjuk kepada pemberitahuan oleh satu negara kepada negara-negara peserta lain bahwa pihaknya bermaksud menarik diri dari traktat. Biasanya, traktat itu sendiri mengatur tentang denunsiasi dengan persetujuan peserta lain memiliki hak denunsiasi. Namun, dalam hal tidak adanya ketentuan demikian, maka denunsiasi dan penarikan diri tidak diperkenankan dan semua peserta lain harus menyetujui kaidah tentang denunsiasi atau penarikan diri. ${ }^{71}$

Oleh karena itu, hal ini menjadi suatu pertimbangan juga dalam hal penarikan diri akibat dibatalkannya Undang-Undang Pengesahan Perjanjian Internasional. Dampak politik yang dapat dirasakan dalam pergaulan internasional Indonesia akan terjadi atau dianggap tidak mampu memberikan kepastian hukum. Kesulitan praktis berkenaan dengan penarikan diri oleh satu negara adalah kemungkinan timbulnya kesulitan terhadap negara-negara peserta lain, yang menginginkan untuk meneruskan keikutsertaan dalam traktat terkait, karena mengganggu keseimbangan umum hak-hak dan kewajiban-kewajiban yang sejak awal telah ditetapkan oleh traktat tersebut. Disamping itu, gugatan kepada Mahkamah Internasional juga dimungkinkan melihat bahwa perjanjian internasional dapat membebankan kewajiban. Sehingga ketika penarikan diri dianggap sebagai suatu pelanggaran terhadap kewajiban suatu

${ }^{69}$ Harjono, “Aspek-Aspek Yuridis Pembuatan Perjanjian Internasional dalam Sistem UUD 1945”, Op.Cit., h. 137 .

70 Jimly Asshiddiqie, Hukum Acara Pengujian Undang-Undang, Op.Cit., h. 48-49.

71 J.G Starke, Op.Cit., h. 625-626. 
negara, maka negara pihak lain bisa saja mengajukannya sebagai sengketa di hadapan Mahkmah Internasional. Sementara ketika dinyatakan bersalah maka negara harus menghormati putusan dan melaksanakan putusan pengadilan sesuai tuntutan negara pihak lain.

Padahal patut diingat bahwa kebebasan telah diberikan sepenuhnya kepada negara untuk meratifikasi sebuah perjanjian internasional atau tidak. Tidak ada suatu kewajiban untuk meratifikasi suatu perjanjian internasional sebagai penghormatan terhadap prinsip kedaulatan. Sehingga seharusnya, segala proses dalam hukum nasional telah dilakukan dan permasalahan dalam hukum nasional telah diselesaikan sebelum akhirnya membuat keputusan untuk meratifikasi perjanjian internasional tersebut. Hal ini penting agar tidak terjadi inkonsistensi suatu negara terhadap perjanjian internasional.

Selain itu, UU Perjanjian Internasional juga telah menciptakan instrumen yang dikenal dengan Pedoman Delegasi, yang memuat latar belakang permasalahan, analisis permasalahan ditinjsu dari aspek politis dan yuridis serta aspek lain yang dapat memengaruhi kepentingan nasional Indonesia, posisi Indonesia dan saran serta penyesuaian yang dapat dilakukan untuk mencapai kesepakatan. Namun, mengingat pesatnya interaksi antarnegara serta banyaknya perjanjian-perjanjian yang harus dibuat secara cepat, maka demi kepentingan praktis acapkali pedoman ini tidak disusun sebagaimana mestinya. ${ }^{72}$ Padahal Pedoman Delegasi seharusnya menjadi hal yang sangat penting sebagai dasar dari keinginan negara untuk menentukan posisi negara dalam sebuah perjanjian internasional. Selain itu jika terjadi sengketa ketatanegaraan yang mempersoalkan status suatu perjanjian yang dibuat oleh Indonesia, maka dokumen Pedoman Delegasi RI menjadi sangat esensial. Pedoman Delegasi yang disetujui oleh Menteri Luar Negeri tersebut diharapkan telah memuat kehendak negara/posisi negara dalam sebuah perjanjian internasional yang sepatutnya dibuat dengan telah memperhitungkan bahwa hal ini tidak bertentangan dengan konstitusi.

\section{Kesimpulan}

Pada umumnya ratifikasi perjanjian internasional diwujudkan melalui dua tahapan, yaitu tahapan hukum nasional dan tahapan hukum internasional. Dalam sistem pemerintahan yang demokratis, pengesahan perjanjian Internasional oleh pemerintah baru dapat dilaksanakan setelah mendapat persetujuan dari parlemen. Setelah perjanjian Internasional mendapat pengesahan, kemudian dimuat dalam dokumen ratifikasi. Hal demikian berlaku di Indonesia dimana dalam rangka meratifikasi maka sebuah perjanjian internasional dalam yuridis formilnya dilakukan pengesahan perjanjian internasional terlebih dahulu yang dimuat dalam format undangundang jika memenuhi syarat Pasal 10 UU Pembentukan Peraturan Perundang-Undangan dan dalam bentuk keputusan presiden jika memenuhi syarat Pasal 11 UU Pembentukan Peraturan Perundang-Undangan. Setelah adanya pengesahan tersebut baru dapat dilakukan proses ratifikasi/eksternal melalui instrument of ratification. Sehingga pemahaman bahwa undang-

\footnotetext{
72 Damos Dumoli Agusman, Op.Cit., h. 50.
} 
undang atau keputusan presidenlah yang mengesahkan perjanjian adalah sangat keliru jika dikaitkan dari realitas praktik hukum yang sebenarnya. Keterikatan Indonesia pada perjanjian tidak bergantung pada undang-undang/keputusan presiden yang mengesahkannya, melainkan bergantung pada piagam ratifikasi (instrument of ratification) serta aturan pemberlakuan yang ditetapkan oleh perjanjian itu sendiri.

Undang-Undang Nomor 24 tahun 2000 tentang Perjanjian Internasional selanjutnya mengadopsi istilah "ratifikasi" dan menerjemahkannya dengan istilah "pengesahan". Padahal makna "persetujuan DPR" yang melakukan pengesahan harus dipandang dalam konteks prosedur internal sementara ratifikasi yang sebagai prosedur eksternal. Oleh karena sebagai prosedur internal, maka hakikatnya undang-undang ini sebagai undang-undang formal, sebagai syarat untuk memenuhi Pasal 11 UUDNRI 1945 mengenai adanya "persetujuan DPR". Meskipun demikian, masi terdapat perdebatan tentang pandangan terhadap kedudukan perjanjian internasional dalam hukum nasional mengenai apakah dengan UU pengesahan maka perjanjian internasional tersebut serta merta berlaku atau apakah secara inkorporasi atau membutuhkan transformasi khusus, hal ini masih butuh pembahasan yang lebih lanjut.

Pengujian konstitusional dilakukan untuk memastikan bahwa tidak ada undang-undang yang bertentangan dengan konstitusi. Namun, pengujian konstitusional bterhadap undangundang pengesahan perjanjian internasional dapat memberikan akibat hukum yang cukup luas dan problematik. Jika dinyatakan batal maka belum ada mekanisme tentang tata cara pelaksanaan putusan tersebut terhadap hal ini. Sehingga posisi Pemerintah akan mengalami kesulitan. Kesulitan yang dimaksud adalah misalnya dinyatakan batal dan harus dilakukan penarikan diri pada perjanjian tersebut maka pemerintah mengajukan denunsiasi tetapi ketentuan untuk boleh menarik diri atau tidak, tergantung dari perjanjian dan kesepakatan negara-negara lain. Apabila negara lain tidak setuju maka penarikan diri tidak dapat dilakukan. Dalam posisi itu maka dalam hukum nasional pemerintah dapat dianggap tidak mampu melaksanakan putusan Mahkamah konstitusi yang final dan binding. Padahal pemerintah memang tidak bisa memaksakan persetujuan terhadap penarikan dirinya. Di samping itu, dampak politik juga akan dirasakan. Inkonsistensi pemerintah Indonesia dalam mengikatkan diri terhadap sebuah perjanjian internasional dapat memberikan citra yang buruk terhadap negara karena tidak bisa memberikan kepastian hukum. Akibat hukum lainnya yang dapat terjadi adalah diajukannya hal ini ke Mahkamah Internasional.

\section{Daftar Bacaan \\ Buku}

Asshiddiqie, J, Gagasan Dasar tentang Konstitusi dan Mahkamah Konstitusi, Artikel Ketua Mahkamah Konstitusi.

-------, Konstitusi \& Konstitusionalisme Indonesia, Sinar Grafika, Jakarta Timur, 2010.

-------, Model-Model Pengujian Konstitusional di Berbagai Negara, Konstitusi Press, Jakarta, 
2005.

------, Hukum Acara Pengujian Undang-Undang, Yarsif Watampone, Jakarta, 2005.

Aust, Anthony, Handbook of International Law, Cambridge University Press, Cambridge, 2005.

Dorr, Oliver dan Kristen Schmalenbach, Vienna Convention on the Law ofTreaties; A Commentary, Springer-Verlag Berlin Heidelberg, London, 2012.

Dumoli Agusman, Damos, Hukum Perjanjian Internasional; Kajian Teori danPraktek, PT. Refika Aditama, Bandung, 2010.

Harjono, "Ratifikasi Perjanjian Internasional", Yuridika-Majalah Fakultas Hukum Unair, No. 4 Th. VIII, Agustus, 1993.

Harjono, “Aspek-Aspek Yuridis Pembuatan Perjanjian Internasional dalam Sistem UUD 1945”, Disertasi, Fakultas Hukum Universitas Airlangga, Surabaya, 1994.

Harjono, Politik Hukum Perjanjian Internasional, PT. Bina Ilmu, Surabaya, 1999.

Holikin, M. Nur S, et.al., Pengujian Undang-Undang dan Proses Legislasi, Pusat Studi dan Kebijakan Indonesia, Jakarta, 2007.

Hollis, Duncan B., Merritt R. Blakesle dan L. Benjamin Ederington, NationalTreaty Law and Practice, Martinus Nijhoff Publisher, Leiden-Boston, 2005.

Manuputy, Alma, et.al, Hukum Internasional, Penerbit Rech-ta \& PusatPenerbitan FH UH, Depok, 2008.

Mauna, Boer, Hukum Internasional; Pengertian, Peranan dan Fungsi dalam eraDinamika, PT. Alumni, Bandung, 2008.

Parthiana, I Wayan, Hukum Perjanjian Internasional Bagian 2, Mandar Maju, Bandung, 2005.

Putusan Mahkamah Konstitusi Nomor 33/PUU-IX/2011.

Siahaan, Maruarar, "Checks and Balances dan Judicial Review dalam Legislasi di Indonesia”, www.jimlyschool.com/read/analisis/333/checks-and-ba;lances-dan-judicial-reviewdalam-legislasi-di-indonesia, 3 Juli 2012, dikunjungi pada tanggal 9 Juni 2013, dikutip dari Jutta Limbach, The Concept of The Supremacy of the Constitution, dalam "The Modern Law Review”, Vol. 64, No. 1, Januari, 2001.

Sinclair, I. M., The Vienna Convention on The Law of Treaties, Manchester University Press, Manchester, 1973.

Starke, J.G., Pengantar Hukum Internasional 1 Edisi Kesepuluh, Cet. X(terjemahan Bambang Iriana Djajatmadja), Sinar Grafika, Jakarta, 2010. 
Sunyowati, Dina, Enny Narwati, dan Lina Hastuti, Buku Ajar: Hukum Internasional, Pusat Penerbitan dan Percetakan Unair (AUP), Surabaya, 2011

Suraputra, D. Sidik, Ratifikasi Perjanjian Internasional Menurut Tiga Undang-Undang Dasar Indonesia, Hukum dan Pembangunan, No. 3 Th. XX, Juni, 1990.

Tjitrawati, Aktieva Tri, Jani Purnawanty, Buku Ajar; Hukum Perjanjian Internasional, Pusat Penerbitan dan Percetakan Unair (AUP), Surabaya,2012.

Villiger, Mark E., Commentary on the 1969 Vienna Convention on the Law ofTreaties, Martinus Nijhoff Publiser, Leiden-Boston, 2009. 